\title{
The Effect of Teacher Certification Motivation and Benefits on Teacher Performance in State Junior High School in Ogan Komering Ilir District
}

\author{
M. Amin ${ }^{1 *}$, Bukman Lian², Mulyadi ${ }^{2}$ \\ ${ }^{l}$ SMP Negeri OKI \\ ${ }^{2}$ Universitas PGRI Palembang \\ *Corresponding author. Email: m.aminusman68@gmail.com
}

\begin{abstract}
The purpose of this research is to provide a clear description of the influence of teacher motivation and certification allowances on teacher performance, either partially or simultaneously. In conducting the research, researchers used quantitative methods as the characteristics of this study which tested the hypothesis. The results obtained from the research conducted were that motivation had a partially positive and significant influence on teacher performance. Teacher certification allowances partially have a positive and significant impact on teacher performance. In simultaneous testing, it was stated that the motivation and allowances for teacher certification had a positive and significant effect on the performance of teachers at SMP Negeri in Ogan Komering Ilir Regency. Therefore, the alternative hypothesis for this study is accepted as a whole.
\end{abstract}

Keywords: Motivation, Teacher Certification Allowances, Teacher Performance

\section{INTRODUCTION}

Education in Indonesia in general has experienced significant movements, one of which is by removing the national exam as the only requirement for graduation. Currently, there are many factors that become requirements for graduation, one of which is the national exam. However, the existence of the national exam is not a threat but rather becomes a benchmark in order to equalize the quality of education nationally. This is an idea worthy of appreciation.

The elimination of the national exam is believed to be able to increase the enthusiasm of teachers to make their students excel. That means the teacher will be motivated to provide an interesting learning experience in each learning process. Because, in learning, teacher motivation is needed so that the implementation of learning will be more effective, and the implications for the results achieved will be maximized. The achievement of the results for teachers is known as teacher performance, as well as the results achieved by students in understanding the learning material.

Teacher motivation is crucial in carrying out their responsibilities; work performed with high motivation is more meaningful. Motivation is derived from the word motive, which means "the force inside a person that induces the individual to act or act." Motivation is a mechanism that describes an individual's strength, direction, and perseverance in achieving his objectives.

That is why someone, especially an educator who provides knowledge and learning to students, is important to have and foster motivation in carrying out their duties. If an educator is able to motivate himself, it is assumed that he will be able to motivate his students. If the teacher has high motivation, then his performance should be better.

As a professional educator, a teacher who has a good performance has the right to receive recognition for his professionalism. This is in accordance with the statement stated in the Regulation of the Minister of Education and Culture Number 23 of 2017 concerning School Days, especially in article 1 paragraph (3) it is stated that teachers are professional educators with the main task of educating, teaching, guiding, directing, training, assessing, and evaluating students in early childhood education through formal education, basic education, and secondary education [1].

The same thing is stated in Law Number 14 of 2005 concerning Teachers and Lecturers, especially in article 1 paragraph (1) it is stated that teachers are professional educators with the main task of educating, teaching, guiding, directing, training, assessing and evaluating participants. students in early childhood education 
through formal education, basic education, and secondary education [2].

The Constitution regulates and states that a teacher is a professional staff, which means that they have broad duties and authorities in their field of expertise, namely to educate, direct, guide and transform knowledge through learning. For this hard work, professional teachers should get an award for what they have done. One form of award given by the government is to provide a professional certificate known as teacher certification.

Teacher certification is given according to the work performance of the teacher, and takes into account the competencies of the teacher concerned. That way, giving teacher certification becomes an additional motivation for teachers to continue to improve their performance. Along with the existence of teacher certification, it will have an impact on the teacher's income. If the teacher has been declared professional by being proven certified, the teacher in question will receive additional income in accordance with the applicable regulations.

The certification allowance is provided in order to fulfill the welfare of teachers. The certification allowance is a form of allowance provided by the government in order to reward teachers as someone who has professional competence. Professional allowances or certification paid through deconcentrating funds are allowances given to non-PNS teachers and PNS teachers who are under the guidance of the provincial education office as well as teachers appointed in the supervisory position of education units, who are appointed by the local government or foundations / community education providers whether teaching in public and private schools, as well as those that already have educator certificates and meet other requirements.

Teachers who have high motivation will be more motivated by the provision of teacher certification allowances. For this reason, there will be an assumption that if teachers have high motivation and are also given a certification allowance as a reward for their professionalism, of course the teacher's performance must be better. To answer this assumption, this research is important to do.

Teachers have a very large role in education, and they are burdened with a responsibility for the quality of education. Therefore, the teacher must develop himself with the knowledge and skills needed in learning. Schools are now faced with competition and technology that is not national but international, both public and private schools. Therefore, the professionalism of a teacher must be followed by the work motivation of the teacher in developing the curriculum at school, it will be useful, if the teacher has the desire, responsibility, interest, appreciation and improves himself in carrying out teaching activities. Likewise, teacher performance is determined by the level of professionalism of the teacher, motivation and work environment.

The description above makes this research even more interesting to do, because the same thing is indicated also happening in the location that is planned to be the object of research. Some of the problems identified by the researcher when conducting the preliminary study were that the motivation of the teachers who taught was quite varied, so that each teacher had a way of carrying out his professional duties. However, if it is seen from the presence of teachers in schools, there are still teachers who have been certified but their attendance is less than $90 \%$. Likewise, with the teacher certification allowance, it is known that the implementation of learning by certified teachers has not increased compared to before being certified. What is also a finding is that the learning administration is not optimal. This information was obtained from the principal who served at the State Junior High School in Ogan Komering Ilir Regency. These are some of the problems that make this research important.

\section{METHODS}

This research was conducted at State Junior High Schools in Ogan Komering Ilir Regency. Starting from July to September 2020. This research was carried out using quantitative methods. The quantitative approach is the approach used by researchers in research by measuring variable indicators so that a general description and conclusions of the research problem can be obtained [3].

The quantitative approach is a method of problem solving that is planned and careful, with a tightly structured design, systematically controlled data collection and is aimed at developing theories that are concluded inductively within the framework of empirically proving the hypothesis. This type of descriptive research with a quantitative approach is the type used in this research. The quantitative research method is a research method based on the philosophy of positivism, used to research on certain populations or samples, data collection using research instruments, quantitative data analysis, with the aim of testing predetermined hypotheses [4].

The quantitative approach is an effort to measure the variables in the study (variables X1, X2 and Y) to then look for the relationship between these variables. This study uses quantitative methods with correlational research because this study aims to see the relationship between variables. Pearson product moment correlation is a technique to find a correlation between two variables that is often used. This correlation technique was developed by Karl Pearson, who is often known as the Pearson Correlation Technique [4].

The population in this study were 526 people, and 211 were used as samples obtained through purposive sampling technique. Data obtained through questionnaires and documentation. The data obtained were then analyzed through parametric statistics using the $\mathrm{t}$ test and $\mathrm{F}$ test. 


\section{RESULTS AND DISCUSSION}

The data obtained from the implementation of the study had tested the prerequisites which stated that the data were normally distributed and there were no symptoms of heteroscedasticity. Therefore, testing can be done with the $t$ test and $F$ test.

Testing the first hypothesis is a test to prove whether there is an effect of motivation on teacher performance. The t-count value for the motivation variable is $11.718>$ $\mathrm{t}$ table is 1.971 , which means that motivation has a positive and significant effect on teacher performance.

The correlation coefficient or the magnitude of the relationship between motivation and the performance of state junior high school teachers in Ogan Komering Ilir Regency is $63.0 \%$, and is included in the strong relationship category. The determinant coefficient or the magnitude of the influence of the motivation variable on the performance of state junior high school teachers in Ogan Komering Ilir Regency is $39.7 \%$ which means it has a low influence.

The second hypothesis testing is hypothesis testing using simple linear regression analysis on the teacher certification allowance variable on teacher performance. The t-count value for the teacher certification allowance variable is $9,752>$ t-table, which is 1.971 , which means that the teacher certification allowance has a positive and significant effect on the performance of teachers at SMP Negeri in Ogan Komering Ilir Regency.

The correlation coefficient or the magnitude of the relationship between teacher certification allowances and the performance of SMP Negeri teachers in Ogan Komering Ilir Regency is $55.9 \%$, and is included in the category of a fairly strong relationship. The determinant coefficient or the magnitude of the influence of the teacher certification allowance variable on the performance of SMP Negeri teachers in Ogan Komering Ilir Regency is $31.3 \%$ which means it has a low effect.

The third hypothesis testing is testing the hypothesis simultaneously or collectively. Taken together, it is meant that in this study there are two independent variables and one dependent variable, testing this third hypothesis simultaneously testing X1X2 against Y. The value of Fcount is 73.7671 and when compared to FTabel of 3.039 it is clear that the motivation and benefits of teacher certification together -sama has a positive and significant effect on the performance of the teachers of the State Junior High School in Ogan Komering Ilir Regency

The correlation coefficient or the magnitude of the relationship between the motivation variable and teacher certification allowances and the performance of the teachers of State Junior High Schools in Ogan Komering Ilir Regency is $64.4 \%$ and is in the category of a fairly close relationship. For the determinant coefficient or the amount of influence simultaneously or simultaneously, the variables of motivation and teacher certification allowances have a $41.5 \%$ effect on the performance of teachers of State Junior High Schools in Ogan Komering Ilir Regency.

\section{The influence of motivation on teacher performance}

The results of this study support research conducted by Safe [5], with a research focus on the effect of certification and motivation on the performance of public high school teachers in Timor Tengah Utara district. The same is true for Istiarini \& Sukanti's research with a research focus on the effect of teacher certification and teacher work motivation on teacher performance at SMA Negeri 1 Sentolo, Kulonprogo Regency in 2012 [6]. The same thing was done by Haryono and Arafat [7]. Each of these research results confirms that every teacher should be able to grow and optimize their motivation so that they can do their job well. Until finally it is expected that the implications for the quality of education as a whole.

\section{The effect of teacher certification allowances on teacher performance}

Other studies confirmed by this study are those conducted by Safe [5], Istiarini \& Sukanti [6], and Melati, Susilaningsih \& Sohidin [8] with a research focus on the effect of teacher certification and teacher work motivation on teacher performance at SMA N 5 Surakarta. As well as research conducted by Muamar, Darmoko, Srifariyati and Muntoha [9] that certification has a major impact on the performance of a teacher.

\section{The effect of motivation and teacher certification allowances on teacher performance}

Overall, the performance of teachers at State Junior High Schools in Ogan Komering Ilir Regency is in the good category. However, it is important for teachers to continue to optimize their performance so that they can further improve the quality of education.

If the two independent variables are tested simultaneously, the magnitude of the effect will be higher when compared to individual or partial testing. These results also confirm that a leader, namely the principal, must be able to provide a stimulus so that the teacher's work motivation will be better, which ultimately has an impact on the performance of the teacher concerned [10], [11].

\section{CONCLUSION}

This study states that there is a positive and significant influence on motivation on the performance of the teachers of State Junior High Schools in Ogan Komering Ilir Regency; There is a positive and significant effect of teacher certification allowances on the performance of teachers in SMP Negeri in Ogan Komering Ilir Regency; There is a positive and significant effect of motivation and teacher certification allowances together on the performance of teachers of SMP Negeri in Ogan Komering Ilir Regency. The magnitude of the effect together is $41.5 \%$. 


\section{REFERENCES}

[1] Kementerian Pendidikan dan Kebudayaan. (2017). Peraturan Menteri Pendidikan dan Kebudayaan Nomor 23 Tahun 2017 tentang Hari Sekolah. Jakarta: Kementerian Pendidikan dan Kebudayaan.

[2] Pemerintah Republik Indonesia. (2005). UndangUndang Nomor 14 Tahun 2005 tentang Guru dan Dosen. Jakarta: Pemerintah Republik Indonesia.

[3] Arikunto, S. (2010). Prosedur penelitian suatu pendekatan praktik. Jakarta: Rineka Cipta.

[4] Sugiyono. 2018. Metode Penelitian Kuantitatif. Bandung: Alfabeta.

[5] Safe, H. (2016). Pengaruh sertifikasi dan motivasi terhadap kinerja guru SMA Negeri di Kabupaten Timor Tengah.

[6] Istiarini, R., \& Sukanti. (2012). Pengaruh sertifikasi guru dan motivasi kerja guru terhadap kinerja guru SMA Negeri 1 Sentolo Kabupaten Kulonprogo Tahun 2012. Jurnal Pendidikan Akuntansi Indonesia, Volume X Nomor 1, 98113.

[7] Haryono, S., \& Arafat, Y. (2017). Effect of organizational culture and work motivation on job performance among the private universities' full-time faculties in South Sumatera Province. Information, 20(8A), 5563-5575.

[8] Melati, F. K., Susilaningsih, \& Sohidin. (2013). Pengaruh sertifikasi guru dan motivasi kerja guru terhadap kinerja guru SMA N 5 Surakarta. Jurnal Pendidikan Ekonomi, 2(1), 71-82.

[9] Muamar, Darmoko, P. D., Srifariyati, \& Muntoha. (2017). Dampak tunjangan sertifikasi terhadap kinerja guru. Jurnal Madaniyah, I(XII), 21-45.

[10] Karweti, E. (2010). Pengaruh kemampuan manajerial kepala sekolah dan faktor yang mempengaruhi motivasi kerja terhadap kinerja guru SLB di Kabupaten Subang. Jurnal Penelitian Pendidikan Vol. 11 No. 2, 77-89.

[11] Mas'ud, \& Saranani, F. (2018). Pengaruh tunjangan sertifikasi dan motivasi kerja terhadap kinerja guru di Kabupaten Konawe Kepulauan. Jurnal Ilmu Manajemen, 4(3), 12-23. 